\title{
Geomorphological and geophysical analyses in a landslide area near Ebermannstadt, Northern Bavaria
}

\author{
Daniel Jäger, Christine Sandmeier, Daniel Schwindt, Birgit Terhorst
}

\begin{abstract}
How to cite:
Jäger, D., SAndmeier, C., Schwindt, D., Terhorst, B. (2013): Geomorphological and geophysical analyses in a landslide area near Ebermannstadt, Northern Bavaria. - E\&G Quaternary Science Journal, 62 (2): 150-161. DOI: 10.3285/eg.62.2.06

Abstract:

The region close to Ebermannstadt is highly prone to landslide activity. Geomorphological mapping, geophysical surveys (electric resistivity and seismic refraction) and substrate analyses were applied to investigate a landslide which was triggered in 1957 The study aims to reconstruct observations of the 1957 event and to compare the earlier situation with the recent surface and subsurface conditions.

It was possible to trace the former observations in the relevant slope area and furthermore, to classify different slide masses and processes. The study also shows area-wide occurrence of ancient slide masses, which were incorporated during the landslide event of 1957. A remobilization of these accumulations cannot be excluded.
\end{abstract}

\section{Geomorphologische und geophysikalische Untersuchungen auf einer Rutschung bei Ebermannstadt, Nordbayern}

Kurzfassung: $\quad$ Die Region um Ebermannstadt ist stark anfällig für Massenbewegungen. Eine Rutschung aus dem Jahr 1957 wurde geomorphologisch kartiert und mit geophysikalischen Messungen (Gleichstromgeoelektrik sowie Refraktionsseismik) untersucht. Die Ziele der Untersuchungen waren eine Rekonstruktion der Beobachtungen von 1957 sowie deren Vergleich mit der heutigen Oberfläche und dem oberflächennahen Untergrund.

Die Ergebnisse zeigen, dass die früheren Beobachtungen auch heute noch Gültigkeit besitzen. Darüber hinaus ist es möglich, einzelne Rutschungselemente und Prozesse zu differenzieren. Die Studie zeigt zudem die Verbreitung von alten Rutschmassen, welche in die Rutschung von 1957 eingebunden waren. Eine erneute Remobilisierung dieser Ablagerungen kann nicht ausgeschlossen werden.

Keywords: $\quad$ Cuesta landscape, Franconian Alb, landslide, earth flow, geomorphological mapping, Electric resistivity tomography, Seismic refraction tomography

Addresses of authors: D. Jaeger*, C. Sandmeier, D. Schwindt, B. Terhorst, University of Wuerzburg, Institute for Geography and Geology, Am Hubland, 97074 Würzburg, Germany. E-mail: Daniel.Jaeger@uni-wuerzburg.de; *corresponding author

\section{Introduction}

Cuesta scarp slopes are highly prone to slide activity due to susceptible geological and geomorphological conditions. The development of cuesta landscapes like the Franconian Alb is controlled by slightly inclined permeable and nonpermeable bedrock. The geological setting results in the characteristic cuesta landforms of almost flat backslopes and steeper front slopes (SCHMIDT \& BEYER 2001). The latter usually consist of steep, sometimes cliff-like upper slopes, formed in the resistant, permeable bedrock and a less inclined lower slope in non-resistant, impermeable layers. This bipartite structure leads to a strong disposition for mass movements. Water can be easily drained through fissures in the upper bedrock - in particular in karstic structures of limestones. In the middle and lower slope areas, impermeable clay- and marlstones lead to an accumulation of water, decreased consolidation and the formation of slip surfaces.

Although mass movements are a common hazard in low mountain areas like the Franconian Alb, only devastat- ing events, endangering buildings, roads or infrastructure are noticed in public (HütTERoTH 1994). Various scientific landslide studies at the Franconian Alb investigate the distribution of landslides for selected regions. In general, the focus is set on internal (lithological, structural and internal morphometric) controlling factors (VON DER HEYDEN et al. 1993, HÜtTEROTH 1994, VON DER HEYden 2004), comparable to studies from other German low mountain areas (e.g. Wenzel 1994, Terhorst 2001, Beyer 2002, Schmidt \& BeyER 2001). Geological studies (e.g. ZürL 1980, HAMmER 1984) primarily comprise soil and rock mechanisms or deal with hydraulic patterns within slide masses.

One of the first works on landslide distribution in the Wiesent River valley was published by DoRN (1920). After the respective movements FreYBerg (1957, 1961), MüLler (1957) and Hegenberger (1961) described visible processes, triggers and morphological landslide elements of the major slides close to Ebermannstadt and provided first information on the slide events. The present study is based on the observations of MüLLER (1957) at the Hasenberg landslide area. 


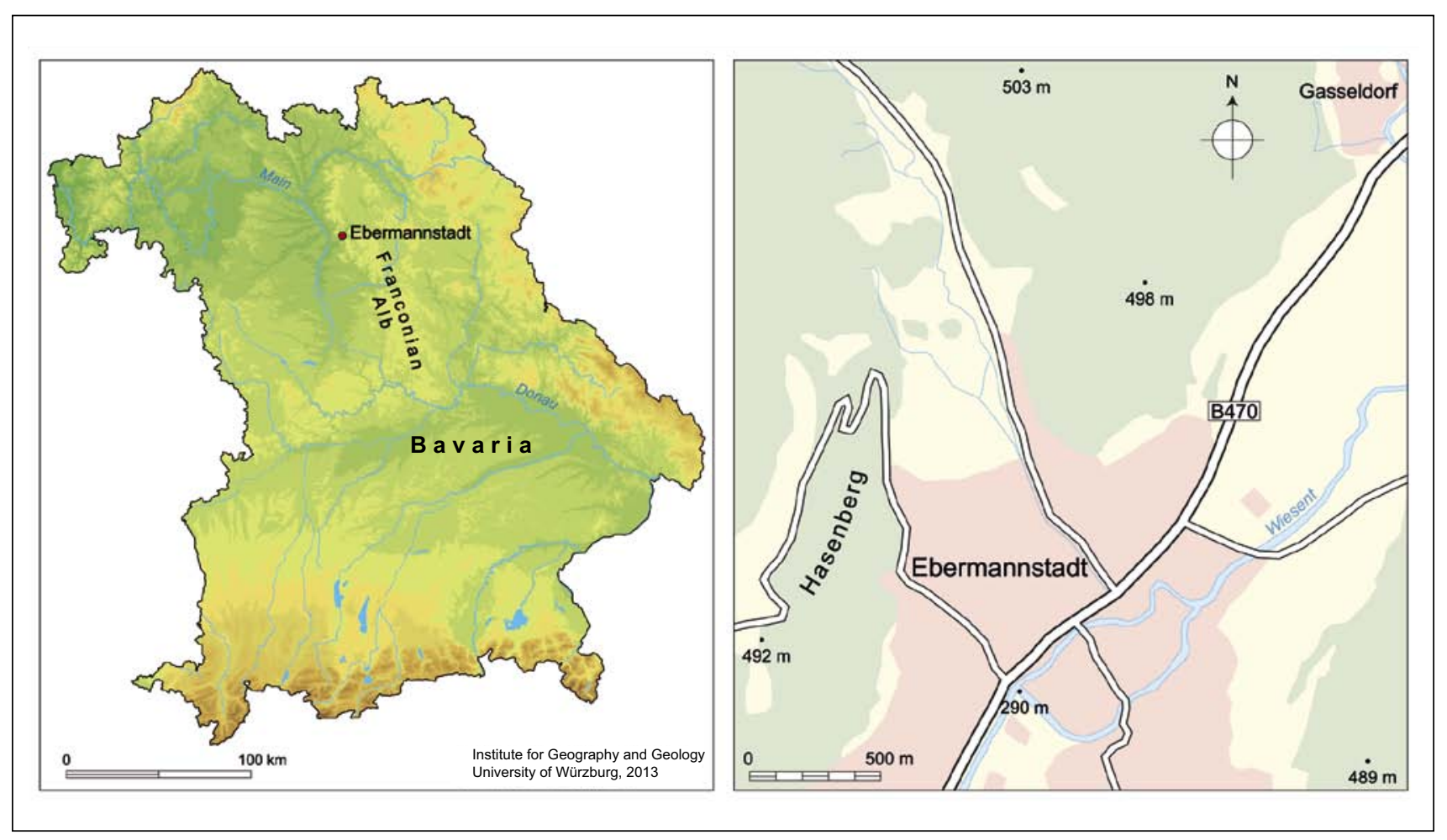

Fig. 1: Location map of the study area.

Abb. 1: Übersichtskarte des Arbeitsgebiets.

In order to analyze controlling factors as well as past processes in the landslide mass, an accurate inventory of the slope is necessary (McKeAn \& Roering 2004). High resolution Digital Terrain Models (DTM) derived from airborne laser altimetry (LiDAR) provide detailed information of the earths' surface (VAN WESTEN et al. 2002) and therefore enable more detailed mapping of relief units, which include landsystem, landform and elementary form (MINAR \& Evans 2008). As surface morphology provides indications for determining the type of a landslide (Hutchinson 1995), high resolution datasets are commonly used for field mappings on any scale (e.g. Montgomery et al. 2000, LEE 2001, Crosta \& Agliardi 2002). The combination of these geo-information tools with additional deterministic input data, such as shallow geophysics, provides a profound method for analyzing landslide hazard and vulnerability as well as risk assessment (BRUNO \& MARTILLIER 2000, VAN Westen et al. 2002).

Within the last decades geophysical methods have developed as standard methods for the minimal-invasive investigation of the shallow subsurface in the fields of environmental research (e.g. TELford et al. 1990; SchrotT et al. 2003; REYNOLDS 2011), and likewise in the studies of landslides (i.e. MCCANn \& Forster 1990; HACK 2000; Bichler et al. 2004; Friedel et al. 2006; Jongmans \& GARAmbois 2007; SchrotT \& SASS 2008; Socco et al. 2010). Recently, the development of $2 \mathrm{D}$ and $3 \mathrm{D}$ techniques can be regarded as a major advance for imaging the often complex and heterogeneous subsurface. A comprehensive review on the geophysical investigation of landslides is given by Jongmans \& GARAmBoIs (2007). So far, no geophysical studies were applied on landslides in the region of Ebermannstadt.

As Müller (1957) described slide processes by the use of geomorphological observations, this study obtains slide processes using surface and subsurface data: A Digital Terrain Model (DTM) was primarily employed for geomorphological mapping, focusing on reconstructing formerly described processes on the surface. Based on these data designated geophysical surveys aimed at obtaining new insights into the subsurface. Besides, the focus was set on defining the type of movement by applying the concepts of VARNES (1978), Hutchinson (1988) and Cruden \& VARnes (1996). A further aim is to assess the susceptibility of the slopes for future movements.

With the towns' expansion already reaching the foot of the landslide, detailed studies of the slide mass are essential for the Hasenberg area.

\section{Regional characteristics and study area}

The study area is situated in the Franconian Alb, approximately $40 \mathrm{~km}$ north of Nuremberg (Fig. 1). The Franconian Alb is part of the south German cuesta landscape, formed by Mesozoic rocks from the upper Triassic, Jurassic and Cretaceous. Related to the occurrence of mass movements, the cuesta scarps of the Rhaethian/Hettangian (Upper Triassic/Lower Jurassic), the Aalenium (Middle Jurassic) and the Oxfordian (Upper Jurassic) are of major interest.

In general, the slopes of the cuesta scarps are affected by different types of mass movements, such as topples, slides, lateral spreads and flows, either in single or in combined occurrence. Falls can be observed on vertical cliffs and fronts of slide blocks. Unconsolidated material and/or old slide masses often cause secondary (translational) landslides.

Due to its extension from north to south, the northern Franconian Alb acts as a barrier for weather-effective air 


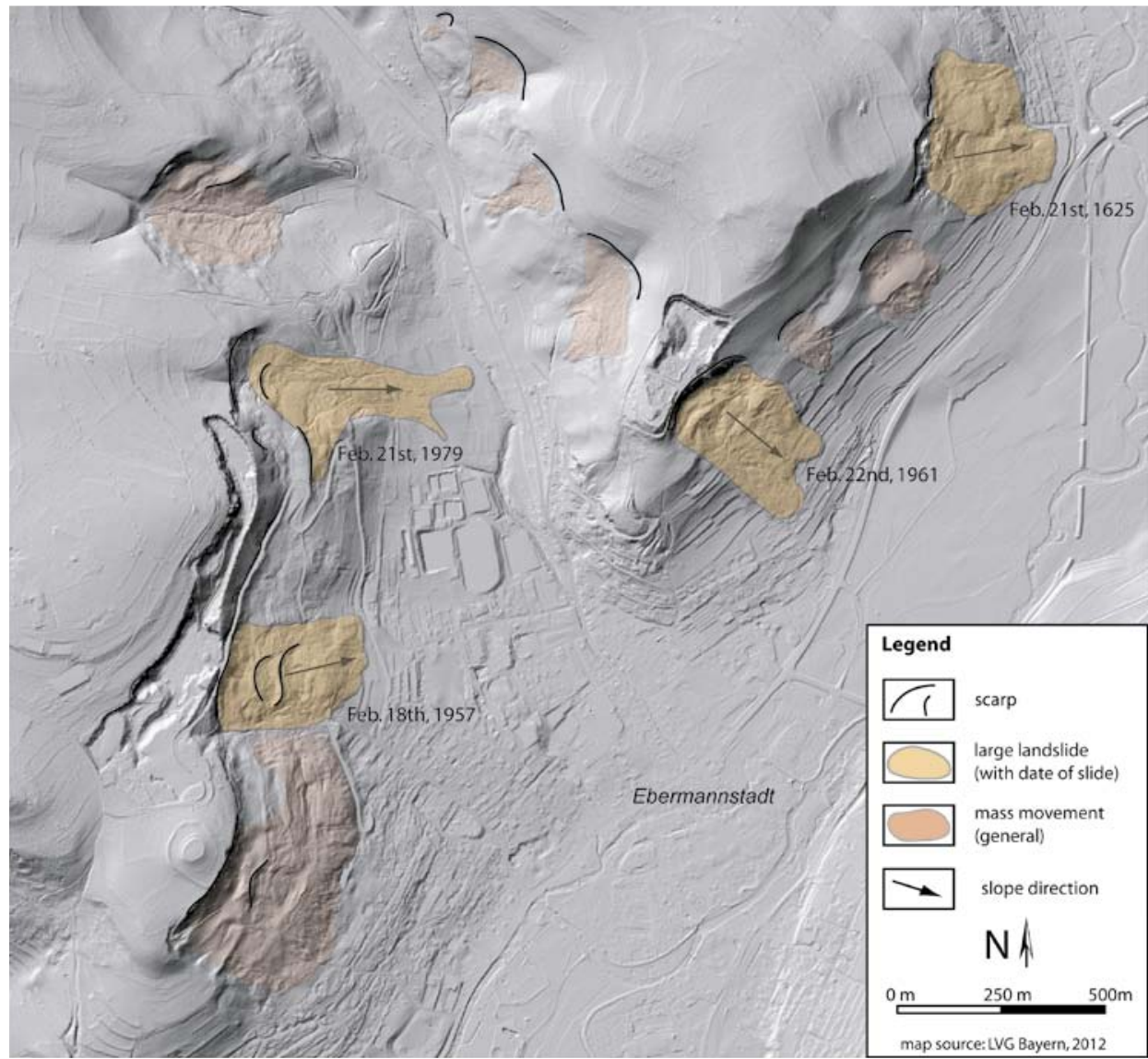

Fig. 2: Mass movements around Ebermannstadt.

Abb. 2: Massenbewegungen im Raum Ebermannstadt. masses coming in from the north Atlantic. As a result, the wind-facing west side of the mountain ridge, where the study area is situated, receives higher precipitation than the western lowlands (Forchheim $684 \mathrm{~mm}$, Ebermannstadt $898 \mathrm{~mm}$ ) (purchased data from DWD (German Meteorological Service)).

Ebermannstadt is located in the broad valley of the Wiesent River at an altitude of $292 \mathrm{~m}$ a.s.l. The adjacent mountains rise up to over $500 \mathrm{~m}$ a.s.l. (Wachknock: $517 \mathrm{~m}$ a.s.l.) and therefore receive a significant amount of precipitation as snowfall during winter.

The geology in the region of Ebermannstadt can be seen as exemplarily for the structure of the Franconian Alb with permeable and impermeable layers. The flat valley floors of the Wiesent river valley, as well as the lower slopes in the region consist of claystones from Lower Aalenian layers (Opalinuston). Above, Upper Aalenian sandstone (Doggersandstein) forms steeper slopes covered by layers of impervious Callovian Claystones (Ornatenton). Most parts of the area are covered by debris from the overlying Oxfordian Limestones (Malm $\alpha / \beta)$. This unit is built up by thick, marly limestones divided by thinner schistose layers. Uppermost parts of the slope are formed by Lower Kimmeridgian Marls and Limestones, the latter of which are mined in the municipal quarry, located above the study area. Measured over a distance of $500 \mathrm{~m}$, all described layers show similar dipping of $8-10 \mathrm{~m}$ (= approximately $\left.1^{\circ}\right)$ towards the east (MÜLLER 1957).

Due to dipping and aspect, several groundwater springs are found on the east-facing Hasenberg. The most important horizons in terms of groundwater springs are the tran- sitions between Lower Aalenian layers and Upper Aalenian Sandstone, as well as between Callovian layers and Oxfordian Limestones. There are no karstic springs found in the vicinity of Ebermannstadt. The mainly concave slopes of the surrounding mountains are often covered by landslide masses, especially in the Eschlipp valley towards the north of Ebermannstadt and on the eastern slopes of the Wiesent valley (Fig. 2).

In 1625, 1957, 1961 and 1979, four major landslides took place around Ebermannstadt (Fig. 2). All of them occurred in the Callovian Clay layers, which underlie the Oxfordian limestones. These geological settings were already described by НüтTEROTн (1994), who investigated mass movements at the "Lange Meile" southwest of Ebermannstadt.

The study area is situated at the eastern flank of the Hasenberg, adjacent to the western town limits, which extend onto the foot of Hasenberg. MüLLER (1957) describes the region at Hasenberg as affected by numerous past landslides, proven by outcrops of landslide derived debris layers. According to MüLLER (1957), lacking soil formation between single debris layers indicate rather close successions of the different mass movements.

\section{Methods \\ 3.1 Geomorphological mapping}

A detailed mapping of surface morphology and existing failures on a slope is fundamental for determining the landslide type (Hutchinson 1995), and for analyzing regional distribution of landslide patterns (GuzETTI et al. 1999, 2000). Therefore, a detailed geomorphological map was cre- 
ated in order to capture this spatial reference of the slopes' structure as well as movement processes and to delineate potential instable areas through localization of active scars and accumulation forms of the 1957-event.

Geomorphological mapping of the present study was based on a 1-m DTM to precisely detect and locate landslide elements. Hence, a reconstruction of processes can be concluded as well as the influence of single geological layers. GIS-derivates, for example hillshades, contour lines, surface curvature, slope gradients and aspect were used during field work and data processing.

The geomorphological mapping was accomplished on a scale of 1:3000. The focus was set on the most important landforms and geomorphological units of the 1957-landslide.

With slight modifications, the symbols for steps, slope gradients, surface and valley forms are based on the mapping keys of Terhorst \& KirschHausen (2001), who developed a legend on mass movements. The mentioned mapping key is based on the geomorphological mapping instructions from LESER \& STÄBLEIN (1978).

\subsection{Geophysics}

Geophysical methods and sites were selected based on the results of the geomorphological mapping and in order to correlate detected landforms to subsurface structures.

Electric resistivity tomography (ERT) measurements were conducted using a 72-channel multi-electrode resistivity meter from IRIS instruments (Syscal Junior Switch) using 36 electrodes per array. With respect to the aimed penetration depth and resolution, a unit electrode spacing of $3 \mathrm{~m}$ has been applied. The array types Wenner (robust; high signal-to noise ratio) and dipole-dipole (more prone to errors, but high sensitivity to horizontal and vertical structures) were used (e.g. Telford et al. 1990; Burger et al. 2006; REYNOLDS 2011).

Three ERT-surveys were conducted, beginning below the debris deposits at $441 \mathrm{~m}$ a.s.l., and ending in the lower parts of the landslide mass at $381 \mathrm{~m}$ a.s.l. (see figure 4). To achieve best possible data coverage within the subsurface, ERT arrays were measured using a roll-along technique with an overlap distance of $15 \mathrm{~m}$ between arrays 1 and 2 and $18 \mathrm{~m}$ between arrays 2 and 3 .
Datasets were concatenated (LOKE 2010) and inverted within the software package RES2DINV (GEOTOMO) using the robust inversion scheme (L1-norm). To reduce sideblock effects an extended model (additional model blocks at both sides and beneath the original data array) was used to calculate resistivity models (LOKE 2010). Areas within the tomograms that are not covered with data points are shaded.

Seismic refraction tomography (SRT)-measurements were conducted using a 24 channel seismograph (Geode) from Geometrics with 24 geophones. A unit electrode spacing of $3 \mathrm{~m}$ has been applied, stating a trade-off between aimed penetration depth and resolution of the subsurface. A $5 \mathrm{~kg}$ sledgehammer was used to generate the seismic signal. To achieve high data coverage, and in consideration of an expected distinct subsurface heterogeneity, shot locations were situated between each geophone pair, as well as in front of and behind the spreads (remote sources), resulting in 25 shot locations per array. As for ERT-measurements, a roll-along technique with an overlap distance of 3 $\mathrm{m}$ between spreads 1 and 2 and $6 \mathrm{~m}$ between spreads 2 and 3 has been applied. More details on the setups of ERT- and SRT-measurements are given in Table 1.

For data processing and inversion the software package SEISIMAGER/2D (GEOMETRICS) with the modules PICKWIN (picking of first arrivals) and PLOTREFA (concatenation of datasets; tomographic inversion) was used. Areas in the tomograms that are not covered by raytraces are shaded to prevent over-interpretations.

The topography of each ERT and SRT survey line has been recorded as the estimated relative vertical distance between two neighbouring electrodes/geophones, to enable an incorporation of relief data into the inversion process within RES2DINV and PLOTREFA, respectively.

\subsection{Substrate analyses}

Along geophysical surveys, additional analyses of substrates were realized to validate and improve the obtained data from geoelectrical and seismic measurements.

A total of 38 study sites in form of small pits of 20-40 $\mathrm{cm}$ in depth were dug over a distance of $380 \mathrm{~m}$. Texture was determined by finger testing according to the Ger-

Tab. 1: Details of the ERT and SRT measurements on Hasenberg study site. Tab. 1: Details der ERT und SRT Messungen im Arbeitsgebiet Hasenberg.

\begin{tabular}{|c|c|c|}
\hline & ERT & SRT \\
\hline \# of concatenated spreads & 3 & 3 \\
\hline electrode / geophone spacing [m] & 3 & 3 \\
\hline \# of electrodes / geophones per spread & 36 & 24 \\
\hline spread length [m] [singe spreads] & 105 & 69 \\
\hline overlap distance [m] & $15 \mathrm{~m} / 18 \mathrm{~m}$ & $3 \mathrm{~m} / 6 \mathrm{~m}$ \\
\hline overall spread length [m] & $282 \mathrm{~m}$ & $246 \mathrm{~m}$ \\
\hline altitude [m a.s.l.] [begin/end of spread] & 381 m / 441 m a.s.l. & 391 m / 427 m a.s.l. \\
\hline \# of stacks & Wenner, dipole-dipole & $25 / 75$ \\
\hline array type / \# of shot points [per array/overall] & & 10 \\
\hline sample interval [ms] & & 0.25 \\
\hline record length [ms] & & 128 \\
\hline
\end{tabular}




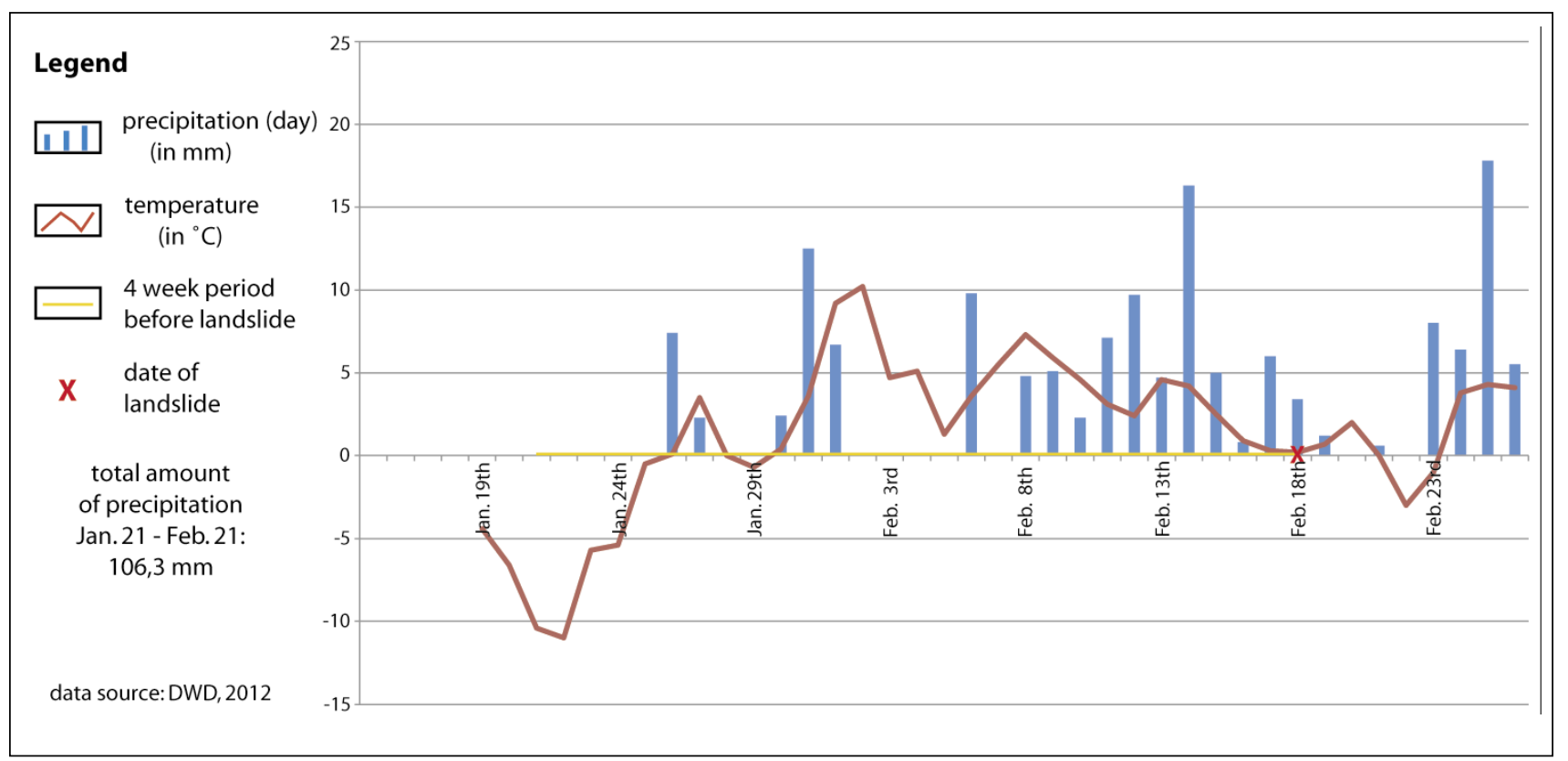

Fig. 3: Precipitation and temperature trend before the landslide of 1957.

Abb. 3: Niederschlags- und Temperaturverlauf vor der Rutschung 1957.

man Field Book for Soil Survey (AD-Hoc-ArbeITsGruppe BODEN 2005).

One focus was set on the occurrence of limestone debris skeleton, which may indicate a slide mass for the middle and lower slope areas. Furthermore, it was important to quantify the amount of fine grained, i.e. clayey material.

\section{History of the landslide at Hasenberg 1957}

The studied landslide at the slope of Hasenberg occurred in late winter of 1957. According to descriptions of MüLLER (1957), slope failure became apparent on February $17^{\text {th }}$, when several cracks opened in the mid slope area of the Callovian Clays covered by Oxfordian Limestone debris. These processes continued for at least twelve hours and initiated further slide movements uphill and flow processes in the lower slope areas. Overall, the landslide covered an area of $225 \mathrm{~m}$ (width) x $350 \mathrm{~m}$ (length) with an estimated volume of approximately $625.000 \mathrm{~m}^{3}$. Average velocity during the major movements was approx. $10 \mathrm{~cm}$ per minute, with local maxima up to $1 \mathrm{~m}$ per minute (MüLLER 1957).

The landslide mass mainly comprises Oxfordian Limestone debris mixed with clay material from Callovian layers. Most parts of the slide mass did not contain fresh limestone fragments but remobilized debris from older slide masses. Furthermore, in the lower parts of the accumulation, upper Aalenian Sandstone fragments were intermingled into the slide mass (MüLler 1957). The upper parts of the landslide area in the Callovian layers were dominated by cracks and slide surfaces, while tongues with an irregular, hummocky surface were formed in the lower areas, underlain by Aalenian layers. Vegetation remained intact on most parts of the landslide, except of the foot. Here, it was destroyed due to the more turbulent flow pattern and the steep front (MÜLLER 1957).

According to MüllER (1957), the landslide in 1957 was presumably triggered by an exceptionally high amount of water input. Meteorological data for late January and February 1957 (see Fig. 3), showed several days of (heavy) rainfalls, summing up to an amount of $107 \mathrm{~mm}$ for the period of 4 weeks before the landslide event. Compared to further datasets between 1931 and 2012, this sum is definitely above the long-term average $(65.9 \mathrm{~mm})$.

On the other hand, precipitations in January of 1957 $(77.8 \mathrm{~mm})$ and December, $1956(55.4 \mathrm{~mm})$ were below average. Furthermore, some years (e.g., 1946 and 1970) show even higher precipitations in February which did not cause landslides in the study area.

Temperature records of early 1957 display values increasing to degrees around zero and above, four weeks before the landslide event. This is supposed to having caused intensive snow melting processes in that time span which lead to a significant increase of the soil moisture (the presence of a snow cover was reported by contemporary witnesses [see MüLlER 1957]). Due to this additional water input, the actual water intake at the Hasenberg slope was much higher than precipitation data proposes. This example illustrates that soil moisture is influenced by different factors (e.g. type of precipitation, snow cover, snow melting, subsurface freezing and others) over a varying time span. Due to its complexity, this factor cannot be discussed in detail in this paper.

\section{Results \\ 5.1 Geomorphological Map}

The first geomorphological map of the slide area after the event of 1957 was published by MüLLER (1957). The map is more of a rough sketch which records the observed processes (e.g., the formation of shear planes), basic geomorphological information (e.g. land surface forms, fissures, scarps) as well as geological layers. The linking of morphological forms to slide processes was limited to a minimal extent. 
Figure 4 shows a detailed geomorphological map of the landslide area based on high resolution DTM. Moreover, a colorized, GIS-processed hillshade combined with slope gradient information provides a precise visualization of the landforms in the study area. The hillshade accurately localizes the geomorphological forms without the problem of GPS-offsets.

The uppermost slope sections are dominated by thick debris deposits. Geologically, this area represents the transition from Oxfordian Limestones (above) to Callovian Clays (below). The area is completely covered by limestone debris and blocks with diameters from a few centimeters to approximately $1 \mathrm{~m}$.

North of the footpath, a large limestone block has been detached from the wall. The rock formation of the block is still intact and can be directly linked to the adjacent rockwall behind. This indicates a relatively constant and slow drifting, without major destruction probably moving on underlying clay layers.

In the upper area of the Callovian Clay (approx. 425-435 $\mathrm{m}$ a.s.l.), slopes are characterized by lower inclinations. Although initial soil formation is present in form of thin litter layers, the area is still dominated by limestone debris. Numerous parallel fissures (orientated rectangular to the slope) are present primarily in the center of the slide area. Most fissures provide widths of approximately $2 \mathrm{~m}$, depths of 1-2 $\mathrm{m}$ and lengths between 5 and $25 \mathrm{~m}$. The proper depth could not be measured exactly as all fissures are partially filled with soil material, debris and/or vegetation. Apart from the widespread mixed forest, vegetation in these areas shows ferns and mosses, which is an indicator for in- creased moisture, probably due to the clayey conditions.

Slide blocks become apparent in lower parts of the Callovian Clay (approx. 405-425 $\mathrm{m}$ a.s.l.). They are characterized by converse uphill slopes, with heights of 1-3 $\mathrm{m}$ and oversteepened downhill slopes. Small areas with a hummocky surface are present in front of larger blocks, due to secondary movements in form of creeping.

The largest block is situated in the center of the landslide area (approx. $410 \mathrm{~m}$ a.s.l.). It forms a significant ridge with a height of $3 \mathrm{~m}$ (view from uphill). The front slope represents a main scarp of the 1957 landslide (total height $12 \mathrm{~m}$ ), with a ruptured surface, indicating intensified movements here. While the upper sections of the front slope are covered by a comparably thin layer of debris, lower areas are buried under large sediment masses. Due to the curved shape of the scarp, a rotational slide can be assumed.

The region downslope (east) of the forest road (approx. at $400 \mathrm{~m}$ a.s.l.) represents the accumulation area of 1957. Most parts of this area are dominated by a wavy pattern, forming relatively smooth surfaces. In the central part a significant "V-shaped" valley, with a maximum depth of $3 \mathrm{~m}$, cuts through the rather flat slide mass. At its lower extensions, remnants of an old pavement become visible, identifying the valley as a former defile (see MüLLER 1957). Remnants of the undisturbed trail allow the reconstruction of its uphill course. It also identifies stagnant and displaced landslide segments: Gaps between single trail segments reveal rates of deposition between 20 to $30 \mathrm{~m}$.

Lower sections of the slide area (around and below the second forest trail in the east, approx. 390m a.s.l.) are again characterized by a wavy surface. At two minor rims, slope

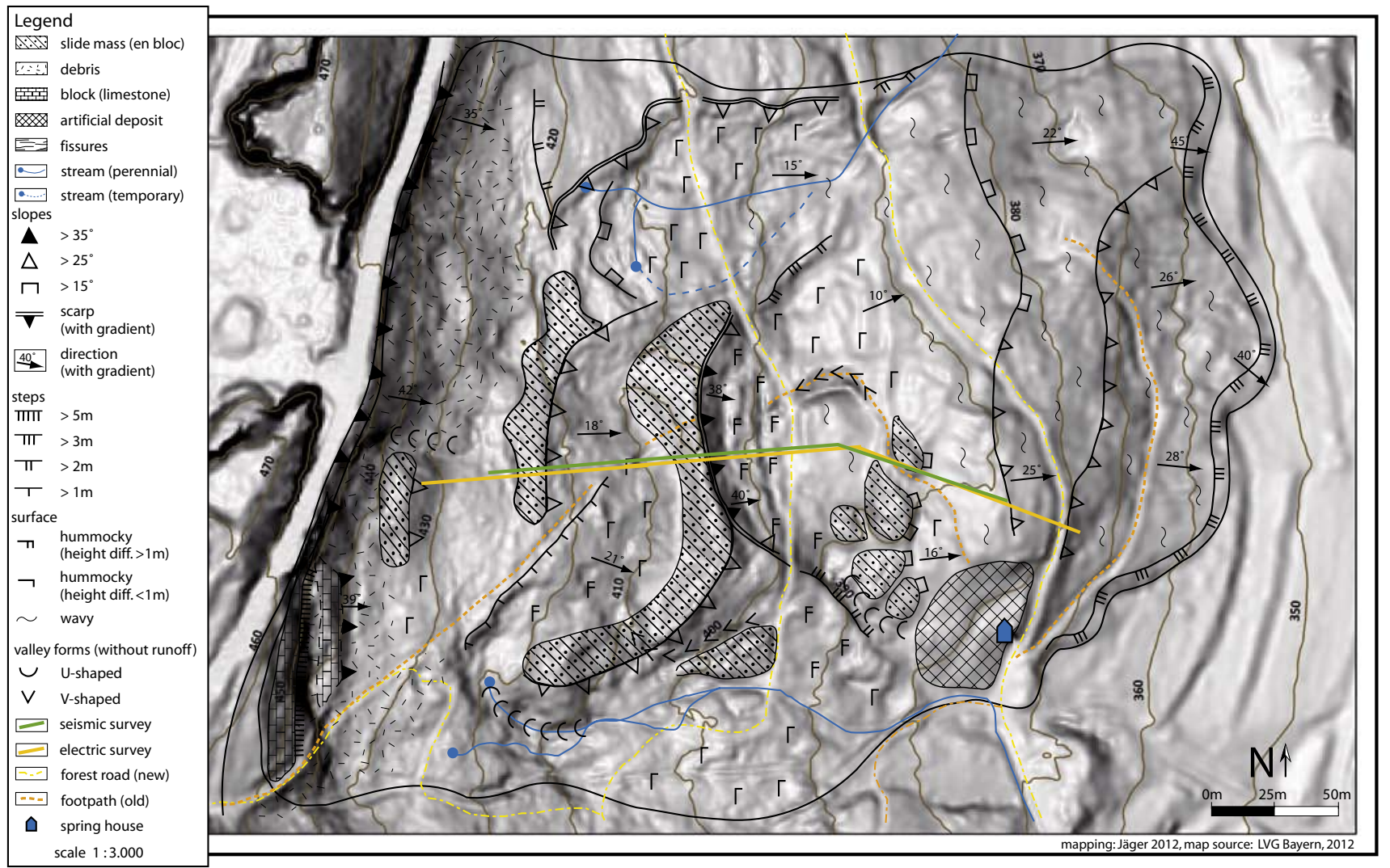

Fig. 4: Geomorphic map of the landslide at Hasenberg. The background map is showing slope gradients.

Abb. 4: Geomorphologische Karte der Rutschung am Hasenberg. Die Hintergrundkarte zeigt die Hangneigungen. 
gradients increase about $5^{\circ}-8^{\circ}$. The toe of the slide mass is formed by a steep step (max. slope gradients $45^{\circ}$ ) with a maximum height between 3-4 $\mathrm{m}$. At this clear boundary the landslide mass can easily be differentiated against the undisturbed surroundings. In the northwestern part, the tip is only 5 meters west of a new road, which has been built after the landslide of 1957.

\subsection{Substrate Analyses}

Figure $5 \mathrm{a}$ outlines the changes of substrate at the surface. The profile is coherent with the geoelectric surveys but extends to the slide's boundaries. In total, substrates were analyzed over a length of $380 \mathrm{~m}$.

Substrate in the steep uphill region is clearly dominated by limestone debris and blocks with maximum diameters of $80-100 \mathrm{~cm}$ and an average of around $20-50 \mathrm{~cm}$. Deposition on the surface is loose due to slope parallel orientation of the fragments' $\mathrm{x}$-axis, with fine-grained material only partially filling the interspaces. Below the depth of $20 \mathrm{~cm}$, initial fillings tend to stabilize the deposit; however, several unfilled cavities are still left. The amount of large debris fragments and blocks decreases downslope in favor of finer material.

The section between the upper ridge and main scarp (horizontal length 100-160 m) offers varying amounts of fine grained material and debris/coarse grains. A composition of limestone fragments embedded in a dense/loamy fine grained matrix characterizes the ridges (such as the upper ridge or main scarp). In contrast, straight slope sections are dominated by clayey material with small amount of coarse grains. Mostly behind (upslope) the ridges, shallow organic horizons $(5-10 \mathrm{~cm})$ could accumulate.

Below the main scarp, a composition dominated by a fine grained, mostly clayey matrix was found. The amounts of limestone debris and coarse grains average approximately $50 \%$. In two small sectors, the amount of clay and fine grains increase to rates of approximately 70-80\%. In any case, clayey material is less dense and slightly less moist compared to the area above the main scarp.

In summary, three different substrate areas could be determined: The uppermost area is dominated by debris and coarse grains while clayey material dominates the midslope sections of the Callovian layers. In the lower parts of the study area, the slide mass contains a composition of both materials.

\subsection{Geophysics}

Figure $5 \mathrm{~b} \& \mathrm{c}$ presents the electrical resistivity- and seismic refraction tomograms in comparison to substrate anal-

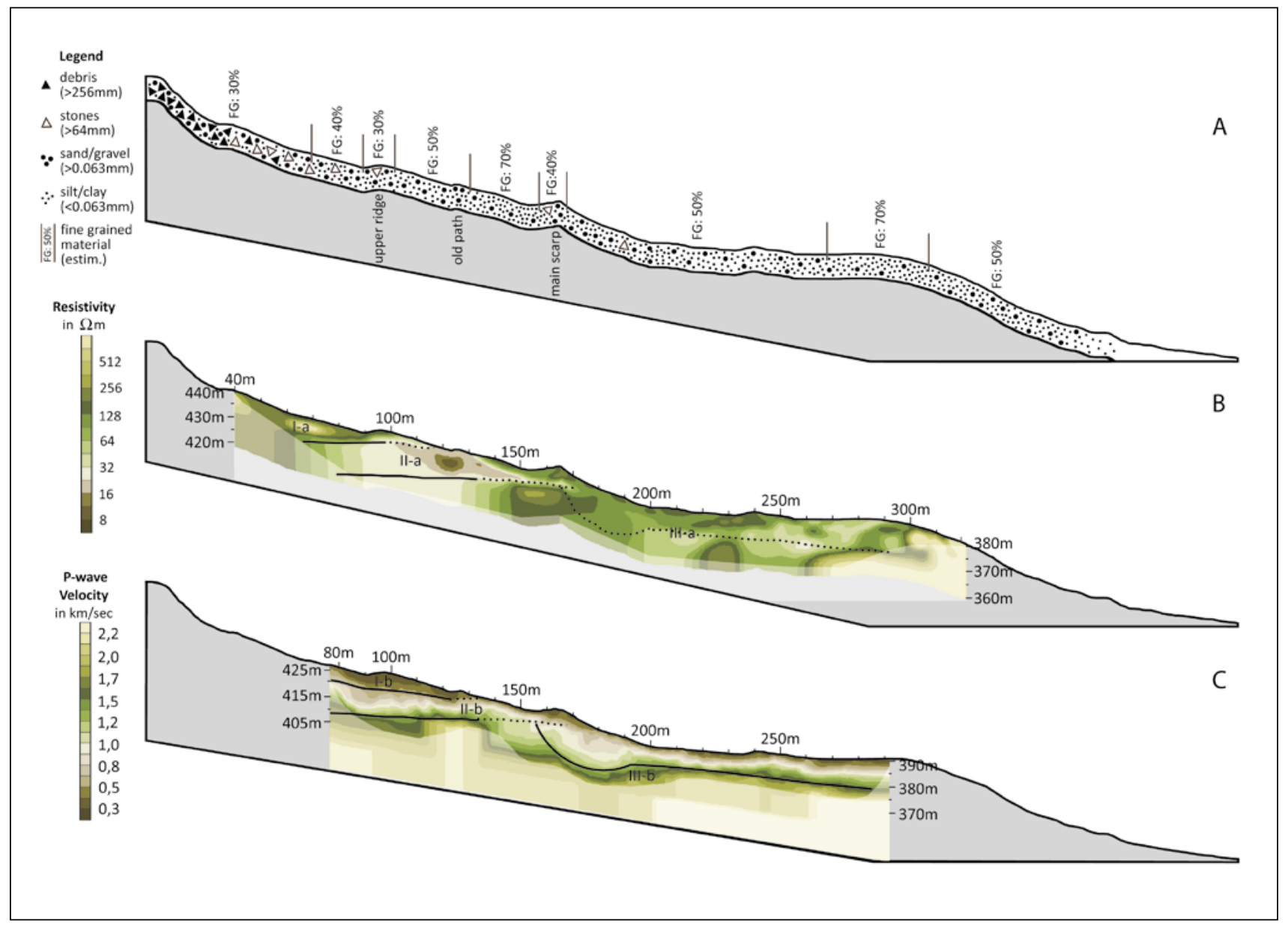

Fig. 5 a, b, c: Profiles showing results drawn from substrate analyses (a), geoelectric surveys (b) and seismic surveys (c). See Fig. 4 for location. The shaded areas could not be interpreted as they are not sufficiently covered by data.

Abb. 5 a , b, c: Profilschnitte mit den Ergebnissen aus Substratanalyse (a), geoelektrischen Sondierungen (b) und seismischen Sondierungen (c). Lagebeschreibung in Abbildung 4. Schattierte Flächen sind nicht ausreichend mit Daten aufgelöst und daher nicht interpretiert. 
yses. Results from ERT and SRT allow for defining three differentiated subsurface sections (see markings in the tomograms) that will be analyzed in the following section.

The subsurface resistivity distribution is recorded over a total profile length of $282 \mathrm{~m}$. The presented tomogram exhibits three major units with varying resistivity characteristics. High resistivities $(\geq 200 \Omega \mathrm{m})$ were obtained in the uppermost region (I-a) and in single spots downslope. Adjacent to this area a unit of very low values $(8-32 \Omega \mathrm{m})$ was measured in the slope section above the main scarp (IIa). The lower half of the profile (III-a) is characterized by mostly intermediate values around 64-128 $\Omega \mathrm{m}$, with several lenses of higher or lower resistivities.

In the uppermost sections (I-a), a relatively homogeneous area with high resistivities $(>200 \Omega \mathrm{m})$ is detected, reaching from the surface as deep as $10 \mathrm{~m}$ (deeper layers cannot be taken into account due to survey geometry). Tapering out downslope, the body covers the top of the small ridge (at $225 \mathrm{~m}$ survey length), before it disappears completely. The transition between sections I-a and II-a is characterized by a sharp boundary and a strong contrast in resistivity values.

Resistivity values in unit II-a are mainly between 24-32 $\Omega \mathrm{m}$, primarily detected for rather homogeneous sections below a depth of $9 \mathrm{~m}$. Within the shallow subsurface (0-9 $\mathrm{m}$ depth) an anomaly with distinct lower resistivity values is detected. Most probably this structure can be ascribed to higher moisture contents there rather than to differing substrate properties. This interpretation is confirmed by substrate analyses that show increased amounts of clayey material. In a depth of approx. $5 \mathrm{~m}$, this unit extends close to the main scarp downslope (horizontal distances 130$160 \mathrm{~m})$. At the surface ( $0-5 \mathrm{~m}$ depth) the unit is covered by a layer of higher resistivity values (max. $100 \Omega \mathrm{m}$ )

From the main scarp to the lower extensions of the survey a heterogeneous resistivity distribution is apparent. The section records an intensively disturbed composition as deep as $15 \mathrm{~m}$. The unit (III-a) can be subdivided into the steep slope section below the main scarp (horizontal distances $165-200 \mathrm{~m}$ ) with resistivity values between $64-128$ $\Omega \mathrm{m}$ and the gently inclined section between horizontal distances $200-300 \mathrm{~m}$. The resistivity distribution in the latter section indicates a vertical differentiation of the subsurface into three layers, with a conductive layer $(5-1.5 \mathrm{~m}$ depth, 24-32 $\Omega \mathrm{m})$ embedded between two layers with higher resistivity values $(>64 \Omega \mathrm{m})$. The conductive layer is horizontally differentiated into three lenses, which are cropping out to the surface between horizontal distances 260-290 $\mathrm{m}$. Upslope (horizontal distances $260-200 \mathrm{~m}$ ) this layer is superimposed by a heterogeneous layer of up to $5 \mathrm{~m}$ in thickness with rather high resistivity values between 64$128 \Omega \mathrm{m}$. The area below $15 \mathrm{~m}$ depth is characterized by a homogeneous resistivity distribution. However, data coverage at this depth is rather poor. In general, the transitions between all parts are relatively smooth.

Seismic surveys cover a total profile length of $215 \mathrm{~m}$. Corresponding to ERT data, three major units can be identified over the course of the profile: (I-b) very low velocities between $0.3-0.5 \mathrm{~km} / \mathrm{sec}$, found at the surface and as deep as 4 $\mathrm{m}$ in the upper regions, as well as at the ridge of the main scarp. This unit is underlain by a section with medium ve- locities (II-b) constantly increasing from 0.5 to $1.2 \mathrm{~km} / \mathrm{sec}$, which also tends to reach the surface in some areas. Unit III$\mathrm{b}$ is characterized by rather fast velocities between 1.2 and $1.7 \mathrm{~km} / \mathrm{sec}$. Acceleration within this unit mostly occurs over short vertical distances.

In the uppermost section, the unit of low velocities (I-b) is dominant at the surface. Below the small upper ridge, velocity slowly increases to $1.1 \mathrm{~km} / \mathrm{sec}$. The only refractor is detected in a depth of $15 \mathrm{~m}$, with velocities rapidly increasing from 1.2 to $1.6 \mathrm{~km} / \mathrm{sec}$ on a vertical distance of approximately $5 \mathrm{~m}$.

The step of the old footpath (horizontal distance $195 \mathrm{~m}$ ) limits the downslope extent of the low velocities at the surface. Here, velocities $>0.9 \mathrm{~km} / \mathrm{sec}$ were obtained at the surface (unit II-b), constantly increasing with depth. Below a depth of $10 \mathrm{~m}$, values increase more rapidly from 1.2 to $\max .2 .2 \mathrm{~km} / \mathrm{sec}$.

This pattern significantly differs from the situation underneath the main scarp. Again, low velocities were found in the surface near layers, similar to the small upper ridge. With depth, they moderately increase forming a pocket of medium resistivities $(0.5-0.9 \mathrm{~km} / \mathrm{sec})$ in the steep area downslope of the main scarp. The pocket is underlain by a refractor as deep as $20 \mathrm{~m}$ forcing velocities to rapidly increase from $1.2 \mathrm{~km} / \mathrm{sec}$ to $1.8 \mathrm{~km} / \mathrm{sec}$.

The gently inclined section between horizontal profile lengths of 200-290 m presents all three units arranged in a uniform subsurface set-up. From the surface as deep as 3 $\mathrm{m}$, low velocities $(0.3 \mathrm{~km} / \mathrm{sec})$ are detected. Velocities constantly increase over a vertical distance of $15 \mathrm{~m}$ to max. 1.8 $\mathrm{km} / \mathrm{sec}$. A refractor can be presumed in a depth of $18 \mathrm{~m}$ due to further velocity acceleration $(>2.0 \mathrm{~km} / \mathrm{sec})$.

\section{Interpretation and discussion}

The region around Ebermannstadt provides three factors favoring landslides: (I) a bipartite geologic structure with permeable and impermeable layers, (II) increased precipitation resulting from conditions at the windward site of the Franconian Alb and (III) dipping towards the direction of the hillslope (in case of east-facing slopes). This leads to the occurrence of several mass movements in the area. As geophysical surveys show, all processes are linked closely to local geology, indicating an important influence of this slope internal factor. The major part of the slope movements occur on the boundary between (Callovian) Clay and debris cover. Obviously, slope parallel dipping of the geological layers additionally favors the development of slip surfaces. As a result, east facing slopes are affected by numerous landslides (MüLLER 1957) as described by DORN (1928).

\subsection{Subsurface structure and formation}

In order to create a generalized model of the 1957 landslide at Hasenberg, geophysical surveys and supporting substrate analyses are combined.

The uppermost slope sections are characterized by debris-rich deposits on the surface. As substrate analyses reveal, a loose accumulation is prevalent. Parts of the interspaces are filled with fine-grained (weathered) mate- 
rial. High resistivity data (unit I-a) and low velocity values (unit I-b) indicate the presence of debris (KNöDEL et al. 2003, REYNOLDS 2011) not only at the surface, but at least as deep as $10 \mathrm{~m}$. Fissures (see Fig. 4) cause reduced interspace-fillings between horizontal distances of $60-80$ $\mathrm{m}$, which is represented by a lens of increased resistivities in this segment.

From top of the survey downslope, the amount and size of limestone blocks and fragments by trend decreases. However, the upper ridge contains a higher amount of debris, as substrate analyses reveal. Again, this is supported by resistivity data and seismic velocities. Both surveys lead to the assumption of comparably solid, debris dominated cover (TELFORD 1990, KNÖDEL et al. 2003, REYNOLDS 2011), approximately 3-5 $\mathrm{m}$ in thickness, building up the ridge. This layer is underlain by unit II-a and II-b values.

Below the ridge (horizontal length 95-125 m) in downslope direction, a denser (packed) and/or moister subsurface is present, due to reduced debris and increased amounts of fine grained material. Seismic velocities at the surface are still low (unit I-b: $0.3-0.6 \mathrm{~km} / \mathrm{sec}$ ) as deep as 4 $\mathrm{m}$. Below, they constantly increase to unit II-b values. The ERT displays considerably lower resistivities, compared to the debris dominated areas upslope. Both, the SRT and ERT values, can be interpreted as a compound of fine grained (clayey) material with a large amount of limestone debris $(>50 \%)$ included (KNÖDEL et al. 2003, BicHLER 2004, REYNOLDS 2011). Moist conditions, indicated by mosses and ferns and also obtained in substrate analyses, cause an additional decrease of resistivities in this area.

Between the small forest trail and the main ridge (horizontal lengths of 130-150 m), substrate analyses revealed considerably higher amounts of clayey material close to the surface. From uphill directions, the course of the old footpath is interrupted in this area, as a gap of approximately $20 \mathrm{~m}$ in length was detected during geomorphological mapping (see Fig. 4 for details). The path can be rediscovered at the main ridge, indicating a displacement in this area. With this in mind, a clayey subsurface appropriate to the formation of slide surfaces is expected. The intermediate surface velocities $(0.5-0.9 \mathrm{~km} / \mathrm{sec})$ exhibited in the SRT clearly support this assumption. Resistivity values between 64-128 $\Omega \mathrm{m}$ (unit III-a) indicate comparably dry composition of clayey material (TELFORD 1990, KNÖDEL et al. 2003, REYNOLDS 2011) and limestone fragments adjacent to the ridge.

To summarize, for the region between 95-165 $\mathrm{m}$ horizontal length, both ERT and SRT assume an extension of the in situ Callovian Clay to altitudes of approximately $422 \mathrm{~m}$ a.s.l. to $408 \mathrm{~m}$ a.s.l. This corresponds with the data of the geological map, which records a thickness of $16 \mathrm{~m}$ (MüLLER 1959) for this layer.

At the ridge of the main scarp, resistivity data (unit III-a) and velocity values (unit I-b) imply a composition of higher amounts of limestone fragments and less fine grains as deep as $5 \mathrm{~m}$ (KNÖDEL et al. 2003, REYNOLDS 2011). The block (with the main scarp) is situated at the lower boundary of Callovian Clays covering Aalenian Sandstone. Both features are assumed to be exhibited in the ERT: A stripe of low resistivities (clay) covers a unit of high resistivities (sandstone) obtained in depths below $10 \mathrm{~m}$. Due to hidden layer effects (see REYNOLDS 2011 for details), SRT is unable to detect the layer of soft clayey material. Constantly increasing velocities reveal no distinguishable refractor, which leads to the assumption of a heavily weathered and shattered structure of the Upper Aalenian Sandstone, assumed as deep as 15-20 m. These characteristics were also stated by MüLLER (1957).

Downslope of the main scarp, a composition of coarse and fine grained (50/50\%) material forms small ridges (e.g. at the steep slope areas below the scarp and at $110 \mathrm{~m}$ and $80 \mathrm{~m}$ survey length) at the surface. Higher amounts $(>50 \%)$ of fine grained, mostly clayey material are found in the gently inclined sections of the accumulation area. As described above, the obtained resistivity data displays varying values in this unit III-a. In ERT, no in situ sandstone could be obtained as deep as $15 \mathrm{~m}$. Poor data coverage prevents the detection of reliable data in greater depths (Telford 1990, KNÖDEL et al. 2003, REYNOLDS 2011). The SRT shows very slow increasing velocities as deep as $12 \mathrm{~m}$, assuming no significant changes in the fine grained slide mass substrate (KNÖDEL et al. 2003, GLADE et al. 2005). For depths of 12-19 m, curved layer structures are clearly visible in the SRT. This structure leads to the assumption of a rotational slip surface present in this area. Rapid increasing velocities in depths below 19 $\mathrm{m}$ mark the surface of rupture and the assumed transition to underlying sandstone.

In the gently inclined slope areas, the SRT exhibits increasing velocities over a vertical distance of $18 \mathrm{~m}$. In combination with the varying resistivity data values, an unconsolidated slide mass, containing stones and debris, embedded in a matrix of fine grained material can be assumed (KNÖDEL et al. 2003, BICHLER et al. 2004, GLADE et al. 2005). Below depths of $15 \mathrm{~m}$, few high resistivity units suggest the presence of fragmented bedrock (Aalenian sandstone) (KNÖDEL et al. 2003). In a corresponding location, the SRT displays no clear refractor, but constantly increasing values. Therefore, this again may be interpreted as an intensively fissured surface of the underlying bedrock (Aalenian sandstone).

\subsection{Morphology, landslide processes and type}

According to MüLLER (1957), the landslide was initiated by movement of water saturated debris in the lower areas of the slide area. Disappearance of the abutment led to further movement of limestone debris and blocks in the upslope regions. MÜLLER (1957) defined the overall movement as an earth flow. This designation was used again by HEGENBERGER (1961), who described the landslide of 1961 at Ebermannstadt Einbühl, which was very similar to the 1957 event. MoSER \& RENTSCHLER (1999) supported this assumption when they investigated types of movement in clay layers of the Franconian Alb. However, as our investigations show, the 1957 event contained heterogeneous material and displayed more processes than a single earth flow.

Detachment of a block from the bedrock took place on the uphill slopes in the southwestern part. A combination of topple (VARNES 1978, DikAU et al. 1996) and creeping (SCHMIDT \& BEYER 2001) processes occur, as the detached 
block is slowly dipping forward while moving downslope on the underlying clay. RADBRUCH-HALL (1978) defines this movement as "creep of blocks over soft rocks". The soft bottom layer also enables rotation of the blocks (BEYER \& SCHMIDT 1999).

Geophysical surveys revealed a shallow translational slab slide (Hutchinson 1988, Dikau et al. 1996) of debris in the clay dominated area uphill of the main scarp. Slab slides frequently occur in debris mixed with fine material (Hutchison 1988). According to Dikau et al. (1996), a shear zone close to the surface is characteristic, as well as movements in slightly weathered bedrock. Both characteristics were obtained at Hasenberg.

The undestroyed part of the footpath on the ridge of the main scarp proves an en bloc movement of this part as suggested by resistivity and seismic data, rather than involvement of buckling, wedging or heaving processes which may also occur at slab slides (Hutchison 1988). The ridge of the main scarp supposably contains a core of (relatively) solid rock. This may be a relic of limestone bedrock or sintered limestone debris, which were observed during field work. Besides, their occurrence on Hasenberg was reported by MülLER (1957). Movement of the block was disrupted at the transition of the Callovian Clay to the underlying Aalenian Sandstones with a clayey slip surface tapering out.

Parts of the block presumably exceeded the step of the underlying Aalenian Sandstone.

At the step, the upper layers of the sandstone are shaped by intensive weathering (MüLLER 1957) and/or prior movements (DorN 1928). Internal weaknesses lead to the formation of a curved slip surface (see SRT) and a small (debris) rotational slide (VARNES 1978, DikAu et al. 1996). The slide also affected the underlying sandstone, as substrate analyses obtained sandstone particles in the slide mass of the main body (see also MüLLER 1957).

Earth flow processes (MüLLER 1957) are characteristic for the lower parts of the slide area and have to be specified as they do not comply with the definitions of VARNES (1978), Hutchinson (1988) or CRUden \& VARnes (1996). In terms of involved material ("earth"), resistivity data and substrate analyses at Hasenberg assume a significant amount of debris embedded in a matrix of fine material. According to the authors mentioned before, the limit of coarse material in an earth flow is $20 \%$ (amounts exceeding $20 \%=$ debris). On the other hand, a review of flow type processes by HungR et al. (2001) determines clay contents of only 10$-70 \%$ for earth flows. Therefore, a distinct definition of the material properties is difficult to apply.

This is also the case in terms of movement mechanism ("flow"). VARnES (1978) classifies all slope movements with internal distortion involved as "flows". However, HungR et al. (2001, p. 222) state, it is "often difficult to determine whether internal distortion or boundary sliding is dominant in a given case". Furthermore, investigations proved that several "flows" moved predominantly by sliding along a shear surface, rather than an irregular flow-pattern (Hutchinson 1970, BRunsden 1984). A coinciding characteristic for flows is a high content of involved water. According to a study of VON DER HEYDEN (2004) the accumulation of a landslide mass on permeable layers (like the Aalenian Sandstone) represents a rather stable condition, as water is able to percolate through debris and subsurface layers. Therefore, a saturation of debris, which may lead to a flow process, is rather unlikely. However, the recent classifications of flows by HuNGr et al. (2001) reveal water contents near the plastic limit as sufficient for a slow moving earth flow.

In the case of Hasenberg, the old road may solve the problem of a designation. Although being displaced with different rates of movement, the old road mainly remained connected (MüLLER 1957). This indicates the existence of one or more relatively coherent masses/blocks with fine grained material involved (see also ERT).

According to the presented literature, movement in the lower parts of the landslide can basically be defined as "earth flow" sensu HuNGR et al. (2001), with the constraint of a coherent mass instead of individually moving particles as mentioned by DikAu et al. (1996).

Concerning the entire landslide, the term "earth flow" is not wrong but rather misleading as it does not reflect the complexity and disparity neither of occurring processes nor of the involved materials.

An enhancement to "complex earth flow" is considered to be necessary. However, as involved material mainly comprises debris and the movements represents typical slide processes (see DikAu et al. 1996, CRUden \& VARnes 1996) the classification of the studied landslide as "complex debris slide" or generalized as "complex landslide" (CRUDEN $\mho$ VARNES 1996) seems to be most appropriate.

\subsection{Future susceptibility}

In order to stabilize the slope some adjustments were achieved after the 1957 landslide. The planting of cottonwood with its shallow roots was meant to stabilize layers close to the surface. However, movements in deeper stages, as detected by geophysical data, cannot be prevented by vegetation. A second regulation was the tapping of springs in order to prevent uncontrolled infiltration of water into the subsurface. This is one of the most important adjustments especially if impermeable layers, e.g. clay, are involved (HAMmER 1984).

Until today, no further landslide has occurred. This is in favor of the interpretation of the Hasenberg as a stabilized landslide area. However, cracks and damages in the road indicate contemporary movements.

Additionally, recent climate change leads to modified precipitation patterns. Most notably, winter precipitation rises (PARRY et al. 2007). Although reliable predictions for this most important trigger factor are not possible yet, a decreasing influence is not assumed. Ongoing investigations especially have to clarify the trend of precipitation along with effects concerning infiltration and consistency boundaries.

Considering all factors, processes and circumstances obtained in the study area are not restricted to the Hasenberg landslide - as illustrated by the event at Ebermannstadt Einbühl (1961) showing similar forms and processes. Also, slopes adjacent to the landslide area provide similar conditions. Assuming certain requirements (intensive snow melting, high precipitation rates), these facts indicate an endangered susceptible slope area. 


\section{Conclusions}

The landslide on Hasenberg from 1957 combined a variation of movement processes like slab slide, rotational slide and earth flow. As a result, the whole movement should be defined as a "complex landslide" or, more detailed, as "complex debris slide".

Slide material is a composition containing varying amounts of limestone debris, clayey material and - in the downslope areas of the study site - fragments of Aalenian Sandstone. In 1957 only little amounts of fresh debris were produced, the majority corresponded to debris which resulted from weathering and/or older slope movements. With exception of the uppermost slope sections, debris contains all grain sizes between clay, silt to stones and debris. The thickness of debris accumulation differs from a few decimeters (covering the slip surface) to more than $10 \mathrm{~m}$ (downslope main scarp).

The obtained processes assume a very close relation to the internal factors of local geology (bipartite structure: permeable and impermeable layers) as well as dipping (analog to exposition). External triggers are (winter) precipitation combined with additional snow melting (and therefore temperature).

After the landslide, necessary adjustments for slope stabilization were achieved. Until today, no further landslide occurred in the study area. However, no guarantee can be given, especially since roadway damage indicates certain movements. Even if the 1957 slide area should be stabilized, similar movements may occur on adjacent slopes.

\section{References}

AD-HOC-ArbeItsgruppe Boden (2005): Bodenkundliche Kartieranleitung. - 438 S.; Hannover (Schweizerbart'sche Verlagsbuchhandlung).

Beyer, I. (2002): Massenverlagerungen an der Wellenkalk-Schichtstufe im Thüringer Becken und ihre Abhängigkeit von morphometrischen Steuerungsfaktoren. - Trierer Geographische Studien, 25: $143-160$.

BEYER, I. SCHMIDT, K.-H. (1999): Untersuchungen zur Verbreitung von Massenverlagerungen an der Wellenkalk-Schichtstufe im Raum nördlich von Rudolstadt (Thüringer Becken). - Hallesches Jahrbuch für Geowissenschaften, Reihe A 21: 67-82.

Bichler, A., Bobrowsky, P., Best, M., Douma, M., Hunter, J., CALVERT, T. \& Bums, R. (2004): Three-dimensional mapping of a landslide using a multi-geophysical approach: the Quesnel Forks landslide. - Landslides, 1(1): 29-40.

Bruno, F. \& Martillier, F. (2000): Test of high resolution seismic reflection and other geophysical techniques on the Boup landslide in the Swiss Alps. - Surveys in Geophysics, 21(4): 335-350.

Brunsden, D. (1984): Mudslides. - In: Brunsden, D. \& Prior, D.D. (ED.) (1984): Slope Instability, Chapter 9: 363-418; New York (Wiley and Sons).

Burger, H. R., Sheehan, A. F., Jones, C.H. (2006): Introduction to Applied Geophysics - Exploring the shallow subsurface. - 600S.; New York (W.W. Norton \& Company).

Crosta, G.B. \& Agliardi, F. (2002): How to obtain alert velocity thresholds for large rockslides. - Physics and Chemistry of the Earth, Parts A/B/C, 27 (36): 1557-1565.

Cruden, D.M. \& VARnes, D.J. (1996): Landslide types and processes. In: Turner, A.K. \& Schuster, R.L. (ed.): Landslides Investigation and Mitigation. National Research Council: 36-75; Washington D.C. (Transportation Research Board, National Research Council).

Dikau, R., Brunsden, D., Schrott, L. \& IBSEN, M.-L. (1996): Landslide Recognition. Identification, Movement and Causes - 251 S.; Chichester (Wiley \& Sons).
DoRn, C. (1920): Bergstürze im Gebiet der Wiesentalb. - Die Fränkische Alb, 6: 18-20.

Dorn, P. (1928): Geologischer Exkursionsführer durch die Frankenalb und einige angrenzende Gebiete. - 183 S.; Nürnberg (Spindler).

FreyberG, B. v. (1957): Bilder vom Bergrutsch bei Ebermannstadt vom 18./19. Februar 1957. - Geologische Blätter NO-Bayern, 7: 125-132.

Freyberg, B. v. (1961): Das Bild des Bergrutsches 1961 vom Einbühl be Ebermannstadt. - Geologische Blätter NO-Bayern, 11: 155-161.

Friedel, S., Thielen, A. \& Springman, S.M. (2006): Investigation of a slope endangered by rainfall-induced landslides using $3 \mathrm{D}$ resistivity tomography and geotechnical testing. - Journal of Applied Geophysics, 60(2): 100-114.

Glade, T. \& DikaU, R. (2001): Gravitative Massenbewegung. Vom Naturereignis zur Naturkatastrophe. - Petermanns Geographische Mitteilungen, 145(6): 42-55.

GuzzetTi, F. (2000): Landslide fatalities and the evaluation of landslide risk in Italy. - Engineering Geology, 58(2): 89-107.

Guzzetti, F. Carrara, A., Cardinali, M., Reichenbach, P. (1999): Landslide hazard evaluation: A review of current techniques and their application in a multi-scale study, Central Italy. - Geomorphology, 31(1-4): 181-216.

Hack, R. (2000): Geophysics For Slope Stability. - Surveys in Geophysics, 21(4): 423-448.

Hammer, H. (1984): Systematische ingenieurgeologische Untersuchung von Hangrutschungen im Nordbayerischen Deckgebirge 255 S.; Nürnberg (Veröffentlichungen Grundbauinstitut Landesgewerbeanstalt Bayern 42)

Hegenberger, W. (1961): Der Bergsturz vom Einbühel bei Ebermannstadt. - Geologische Blätter NO-Bayern, 11: 145-155.

Hungr, O., Evans, S.G., Bovis, M.J., Hutchinson, J.N. (2001): A Review of the Classification of Landslides of the Flow Type. - Environmental \& Engineering Geoscience, VII-3, 221-238.

Hutchinson, J.N. (1970): A coastal mudflow on the London Clay cliffs at Beltinge, North Kent. - Géotechnique, 20: 412-438.

Hutchinson, J.N. (1988): Morphological and geotechnical parameters of landslides in relation to geology and hydrogeology. - Landslides, Proceedings $5^{\text {th }}$ International Symposium on Landslides, 1: 3-35.

Hutchinson, J.N. (1995): Landslide hazard assessment. - In: BelL, D.H. (ed.): Proceedings of the VI International Symposium on Landslides, Christchurch, New Zealand: 1805-1841.

HÜтteroth, W. (1994): Bergrutsche an der nördlichen Fränkischen Alb. - Mitteilungen der Fränkischen Geographischen Gesellschaft, 41: 185-203.

JoHNSEN, G. \& SchmidT, K.-H. (2000): Measurement of block displacement velocities on the Wellenkalk scarp in Thuringia. - Zeitschrift für Geomorphologie N.F., Suppl.-Bd. 123: 93-110.

Jongmans, D. \& GARAmBoIs, S. (2007): Geophysical investigation of landslides: A review. - Bulletin Société Géologique de France, 178 (2): 11.

KANY, M. \& HAMmER, H. (1985): Statistische Untersuchungen von Rutschungen im Nordbayerischen Deckgebirge. - In: HeITfELD, K.-H. (ed.): Ingeniergeologische Probleme im Grenzbereich zwischen Lockerund Festgesteinen: 257-265; Berlin (Springer).

Knödel, K., Krummel, H. \& LANGe, G. (2003): Geophysik. - 1102 S.; Berlin (Springer)

LEE, E.M. (2001): Geomorpological mapping. - In: Griffiths, J.S. (ed.) Land Surface Evaluation for Engeneering Practice: 18, 53-56; London (Engeneering Geology Special Publications).

LESER, H. \& StÄBleIN, G. (1978): Legende der Geomorphologischen Karte 1:25000 (GMK 25). - 3. Fassungen im GMK Schwerpunktprogramm. Berliner Geographische Abhandlungen, 30: 79-90.

LOKE, M. H. (2010): Tutorial: 2-D and 3-D electrical imaging surveys. $127 \mathrm{~S}$.

McCANN, D. M. \& Forster, A. (1990). Reconnaissance geophysical methods in landslide investigations. - Engineering Geology 29(1): 59-78.

McKean, J. $\mho$ Roering, J. (2004): Objective landslide detection and surface morphology mapping using high-resolution airborne laser altimetry. - Geomorphology, 57: 331-351.

MinAR, J. \& EvANS, I.S. (2008): Elementary forms for land surface segmentation: The theoretical basis of terrain analysis and geomorphologica mapping. - Geomorphology, 95: 236-259.

Montgomery, D.R., Schmidt, K.M., Greenberg, H.M., Dietrich, W.E. (2000): Forest clearing and regional landsliding. - Geology, 28(4): 311-314.

Moser, M $\mho$ Rentschler, K. (1999): Geotechnik der Kriech- und Gleitprozesse im Bereich des Juras der Frankenalb. - In: Bibus, E. \& Terhorst, 
B. (ed.) (1999): Angewandte Studien zu Massenbewegungen: 193-212; Tübingen (Tübinger Geowissenschaftliche Arbeiten, D 5).

Müller, K.W. (1957): Der Bergrutsch von Ebermannstadt (Fränk. Alb) vom 18.-19. Februar 1957. - Geologische Blätter NO-Bayern, 7: 119-125.

Parry, M.L., Canziani, O.F., Palutikof, J.P., van der Linden, P.J., HaNson C.E. (eds.): Contribution of Working Group II to the Fourth Assessment Report of the Intergovernmental Panel on Climate Change, 2007. - 976 S.; New York (Cambridge University Press)

RADBRUCH-HALL, D.H. (1978): Gravitational creep of rock masses on slopes. - In: VoIght, B. (ed.): Rockslides and avalanches: 607-675; Amsterdam.

Reynolds, J. M. (2011). An Introduction to Applied and Environmental Geophysics. - 785 S.; Chincester (John Wiley \& Sons)

Schmidt, K.-H. \& Beyer, I. (2001): Factors controlling mass movement susceptibility on the Wellenkalk-scarp in Hesse and Thuringia. Zeitschrift für Geomorphologie N.F., Suppl,-Bd. 125: 43-63.

Schrotт, L. \& SASS, O. (2008): Application of field geophysics in geomorphology: Advances and limitations exemplified by case studies. Geomorphology, 93(1-2): 55-73.

Schrott, L., Hördt, A., DikaU, R. (ed.) (2003). Geophysical applications in geomorphology. - Zeitschrift für Geomorphologie, N.F., Suppl.-Bd. 132: $190 \mathrm{~S}$.

Socco, L. V., Jongmans, D. Boiero, D. Stocco, S., Maraschini, M., Tokeshi, K., HANTZ, D. (2010): Geophysical investigations of the Sandalp rock avalanche deposits. - Journal of Applied Geophysics, 70, 4: 277-291.

Telford, W.M., Geldart, L.P., Sheriff, R.E. (1990): Applied Geophysics ( $2^{\text {nd }}$ edition). -751 S.; Cambridge (Cambridge University Press).

Terhorst, B. \& KirschHausen, D. (2001): Legends for mass movements in the MABIS Project. - Zeitschrift für Geomorphologie N.F., Suppl,Bd. 125: 177-192.
Terhorst, B. (1997): Formenschatz, Alter und Ursachenkomplexe von Massenverlagerungen an der schwäbischen Juraschichtstufe unter besonderer Berücksichtigung von Boden- und Deckschichtenentwicklung - 212 S.; Tübingen (Tübinger geowissenschaftliche Arbeiten, Reihe D 2)

Terhorst, B. (2001): Mass movements of various ages on the Swabian Jurassic escarpment. Geomorphologic processes and their causes. Zeitschrift für Geomorphologie N.F., Suppl.-Bd. 125: 65-87.

VAn Westen, C.J., VAn Asch, T.W.J., Soeters, R. (2006): Landslide hazard and risk zonation - why is it still so difficult. - Bulletin Engeneering Geological Environment, 65: 167-184.

VARnEs D. J. (1978): Slope movement types and processes. - In: Schuster R. L. \& KRIZEK, R. J. (ed.): Landslides, analysis and control. Transportation Research Board Sp. Rep. No. 176: 11-33. Washington, D.C. (National Research Council).

VON DER HEYDEN, D. (2004): Rutschungen an den Malmschichtstufen der nordwestlichen Frankenalb: Untersuchungen zu Formenschatz, Alter und Ursachen (Diss.) - 137 S.; Bamberg (WIKU-Verlag).

Von der Heyden, D., Garleff, K. \& Buschwiewcke, P. (1993): Hangrutschungen um die Altenburg bei Bamberg. - Berichte der Naturforschenden Gesellschaft Bamberg 68: 33-43.

Wenzel, B. (1994): Zur Lithostratigraphie und Sedimentologie des Röt und $\mathrm{zu}$ den Massenverlagerungen an der Röt-/Muschelkalkgrenze in Nordosthessen - 379 S.; Gießen (Gießener Geologische Schriften 53).

ZÜRL, K. (1980): Rutschungen im Ornatenton. - LGA Rundschau 80-1: 14-19.

Purchased Data:

Deutscher Wetterdienst (DWD) (2012): Precipitation Data (per month) of measuring stations Forchheim and Gößweinstein (years: 19312012). 